\title{
Fire Control Efforts in a Cement Company in East Java
}

\section{Upaya Pengendalian Kebakaran Di Perusahaan Semen Jawa Timur}

\author{
Trie Islamy Pangestu Astid Putera ${ }^{1}$, Tri Meidya Rahmawati ${ }^{2}$ \\ ${ }^{1}$ Departmentof Occupational Safety and Health, Faculty of Public Health, Universitas Airlangga \\ ${ }^{2}$ Department of Environmental Health, Faculty of Public Health, Universitas Airlangga \\ Campus C Mulyorejo, Surabaya East Java 60115 Indonesia
}

\begin{abstract}
Introduction: The cement production process uses high technology machines and uses coal as fuel. The potential for fires is huge because in the cement company there are areas that are very vulnerable to fires such as in the coalmill, preheater, and klin areas. The purpose of this study is to describe the description of the causes of fires, fire prevention technical efforts, OSH organization in the field of fire prevention, and personal protective equipment (PPE). Methods: The method used in this research was a descriptive method with cross sectional study design. Data collection was done by means of observation. The research variables used were the causes of fire, fire prevention technical efforts, OSH organization in the field of fire prevention, and Personal Protective Equipment (PPE) for firefighters. The sample used in this study was the entire unit in the cement company. Result: Cement company causes fires, classified in medium criteria. Meanwhile, fire prevention efforts in the cement company is classified in good criteria. Moreover, organizations in the cement company in the fire prevention sector is included in good criteria and the personal protective equipment provided in the cement company is included in good criteria. Conclusion: The cause of the fire in the cement company is the use of coal as the main fuel for the process of making cement, which is also the source of fire. Efforts made by the cement company include the installation of layouts and the installation of evacuation signs on each building. Personal Protective Equipment in the cement company has also been well managed.
\end{abstract}

Keywords: cement, coal, fire, occupational safety and health, personal protective equipment

\section{ABSTRAK}

Pendahuluan: Proses produksi pada Perusahaan Semen menggunakan mesin-mesin canggih dan menggunakan batu bara sebagai bahan bakarnya. Potensi untuk terjadinya kebakaran sangat besar karena di Perusahaan Semen terdapat area yang sangat rentan untuk menyebabkan kebakaran seperti di area Coalmill, preheater, dan Klin. Tujuan dari penelitian ini untuk menggambarkan deskripsi penyebab kebakaran, upaya teknis pencegahan kebakaran, organisasi Keselamatan dan Kesehatan Kerja (K3) dibidang pencegahan kebakaran, serta alat pelindung diri (APD) untuk tim pemadam kebakaran. Metode: Metode yang digunakan dalam penelitian ini adalah metode deskriptif dengan desain studi cross sectional. Pengumpulan data dilakukan dengan cara observasi. Variabel penelitian yang digunakan adalah penyebab kebakaran, upaya teknis pencegahan kebakaran, organisasi K3 di bidang pencegahan kebakaran dan Alat Pelindung Diri (APD). Sampel yang digunakan dalam penelitian ini adalah seluruh unit di perusahaan semen. Hasil: Penyebab kebakaran Perusahaan Semen, didapatkan kriteria sedang. Upaya Pencegahan Kebakaran di Perusahaan Semen didapatkan kriteria baik. Organisasi di Bidang Pencegahan Kebakaran Perusahaan Semen didapatkan kriteria baik dan Alat Pelindung Diri yang telah disediakan di Perusahaan Semen termasuk dalam kategori baik. Simpulan: Penyebab kebakaran pada perusahaan Semen karena penggunaan batu bara sebagai bahan bakar utama untuk proses pembuatan semen dan merupakan sumber api. Upaya yang dilakukan oleh perusahaan Semen meliputi pemasangan tata ruang dan pemasangan rambu evakuasi di setiap bangunan. Alat Pelindung Diri di Perusahaan Semen telah dikelola dengan baik.

Kata kunci: alat pelindung diri, batu bara, kebakaran, keselamatan dan kesehatan kerja, semen

\section{Corresponding Author:}

Trie Islamy Pangestu Astid Putera

Email: trie.islamy.pangestu-2018@fkm.unair.ac.id

Telephone: +6281939351123

\section{INTRODUCTION}

Fire is the emergence of an unwanted fire, whose occurrence is caused by several factors that can result in great losses. Fires in the industry have a high loss rate, and the fire hazards in industry are different from those in other public areas. If 
an industry experiences a fire, the loss is related to high assets owned, the production process, and employment opportunities (Umamah, Denny and Kurniawan, 2015).

The use of coal resources in Indonesia in 2010 amounted to 104.94 billion tons and reserves of its use amounted to 21.13 billion tons. The abundant coal resources in Indonesia have become the choice of companies that make coal a role or substitute for petroleum and natural gas. In Indonesia, coal production is increasing every year, reaching its peak of production in 2009 of 254 million tons (Permana, 2011).

Fire incident is one of the accidents that can occur in an industry and can cause losses to humans, property or other assets owned by the company. According to the Minister of Manpower (1998), workplace accidents are unwanted events and can occur suddenly. Fires that occur in an industry not only cause losses to humans,property and assets, but can also disrupt production operations, which can eventually cause disruption in stability and continuity (Minister of Manpower, 1998).

The first cement production process is carried out by burning a mixture of clay and limestone, so there is adecomposition of limestone $(\mathrm{CaCO} 3)$ to calcium oxide $(\mathrm{CaO})$ and carbon dioxide $(\mathrm{CO} 2)$. Afterwards, limestone reacts with other compounds to form clinkers, which later becomes Portland(Putri and Amri, 2011)

Cement company is one of the factories whose products are cement. The production process at Cement company uses sophisticated machinery and coal as fuel. Based on the identification of aspects and assessment of the impact on Occupational Safety and Health (OSH) activities, the area that has a high risk of fire is the coal mill area. Fires can occur in this area due to coal grinding activities. Friction between coals can cause sparks that are the source of the fire. Fires that often occur in cement companies are usually still able to be overcome by fire extinguishers.

The storage area, coal transportation and coalmill area, preheater area and llin area are areas that are most likely to experience fires in the cement company . These areas often experience fires caused by coal. Coal is a sedimentary rock that can ignite by itself caused by oxidation on the surface of coal that comes in contact with oxygen in the air. Therefore, it is necessary to control fire in the cement company.

Fire control is all efforts done to prevent fires the provision of a fire protection, rescue recommendations and the establishment of an emergency response organization to combat fires (Minister of Manpower, 1999). The purpose of this study is to determine efforts of controlling fire hazards in a cement company, including a description of the causes of the fire, fire prevention technical efforts, Occupational Safety and Health $(\mathrm{OSH})$ organization in the field of fire prevention, and Personal Protective Equipment (PPE).

\section{METHODS}

This research used a descriptive method because it describes a phenomenon that occurs in the community. The research design used was cross sectional because it was carried out at a certain period of time (Notoadmodjo, 2012).

This research was conducted in acement company from March to June 2017. The research was carried out in fire risk areas such as coal storage. The research variables used were the causes of fire, fire prevention technical efforts, the OSH organization in the field of fire prevention, and Personal Protective Equipment (PPE).

The sample used in this study was the entire unit in the cement company, starting from the production unit, storage of raw materials, packing, to the company's management office. Researchers took the entire unit because the researchers wanted to know the overall fire suppression efforts in the cement company.

The primary data were collected through observation and the secondary data were obtained from company profiles and documents. Meanwhile, the observations were made by direct observation in the area of potential fire hazards and fire extinguishers using the observation sheets with the checklist sheet method. The collected data were analyzed descriptively in a tabular and narrative form so that conclusions can be drawn.

In this study, the causes of fire variables are divided into 3 categories. High category refers to a condition wherethere are all factors that cause a fire such as flames, radiation, blasting, sparks, etc. Medium category refers to a condition where there are only a few number of factors causing a fire. Low category refers to a condition where there are no fire-causing factors.

Furthermore, the variable of fire prevention efforts are divided into 3 categories. It falls under the good category if all technical control efforts are carried out such as the storage of combustible 
materials, the provision of barriers to the room, lay out arrangement, and zoning according to the type and level of danger. It falls under the H Bad category means there is no effort made.

Moreover, the OSH organizational variables in the field of fire prevention are divided into 3 categories. Good category is a condition where the company has an organizational structure, each member has his main duties and functions, and there are facilities and infrastructure. Medium category is a condition where the company only has an organizational structure or only has facilities and infrastructure. Bad category is a condition where the company does not have an organizational structure, each member does not have basic duties and functions, and there are no facilities and infrastructure.

Regarding personal protective qquipment variable, the variable is divided into 3 categories. Good category is a condition where the quality and quantity of PPE are in accordance with the needs, and the company always carries out checks and tests on it regularly. Medium category is a condition where the quality and quantity of PPE are not in accordance with the requirements, and inspection and testing on it are rarely performed. Bad category is a condition where the quality and quantity of PPE do not meet the needs, and there is no routine inspection and testing on it.

Besides, in the determination of the criteria, it is considered good if it meets the regulatory requirements, medium if only some have met the requirements, and bad if it does not meet the overall requirements.

\section{RESULTS}

\section{Causes of Fire in the Cement company}

Based on Table 1, each cause of fire is in medium category because there are only a few factors that exist. Fire and irradiation have the potential to occur in the coal Storage area (where the coal storage has been milled). Sparks have the potential to occur in the main substation area (an area to meet the company's electricity). Dust blasting has the potential to occur in the pre-heather area (the initial combustion process of raw materials).

\section{Fire Prevention Efforts}

Based on Table 2, all fire Prevention efforts in the cement company belong to good criteria because all efforts in technical control have been carried out. The storage of flammable materials is carried out in the coal storage area and the bulkhead distribution is carried out in the hazardous and toxic substances storage area.

\section{Occupational Safety and Health Organization of Fire Prevention}

Based on Table 3, every section of the OSH organization of fire preventionin the cement company belong to good criteria because this OSH organization has carried out its main tasks and functions. The OSH organization of fire prevention also has facilities and infrastructure to support fire prevention efforts.

\section{Personal Protective Equipment (PPE)}

Based on the observation, the cement company has provided personal protective equipment with good criteria. This is because both of the quality

Table 1. Data on the Causes of Fire in the Cement Company in 2017

\begin{tabular}{|l|l|}
\hline \multicolumn{1}{|c|}{ Causes of Fire } & Criteria \\
\hline Fire existence & Medium \\
\hline Irradiation existence & Medium \\
\hline Spark existence & Medium \\
\hline Dust blasting & Medium \\
\hline
\end{tabular}

Table 2. Data on Fire Prevention Efforts in the Cement Company in 2017

\begin{tabular}{|l|c|}
\hline \multicolumn{1}{|c|}{ Fire Prevention Effort } & Criteria \\
\hline Providing an Eeplosive material storage & Good \\
\hline Giving barriers & Good \\
\hline Setting the production layout & Good \\
\hline Giving distance between buildings & Good \\
\hline $\begin{array}{l}\text { Zoning according to the type and level of } \\
\text { danger }\end{array}$ & Good \\
\hline
\end{tabular}

Table 3. Data on the Occupational Safety and Health Organization of Fire Prevention in the Cement Company in 2017

\begin{tabular}{|l|c|}
\hline \multicolumn{1}{|c|}{ Section } & Criteria \\
\hline Firefighters & Good \\
\hline Protection Equipment & Good \\
\hline Workshops & Good \\
\hline Safety Officers & Good \\
\hline Quality Control & Good \\
\hline
\end{tabular}




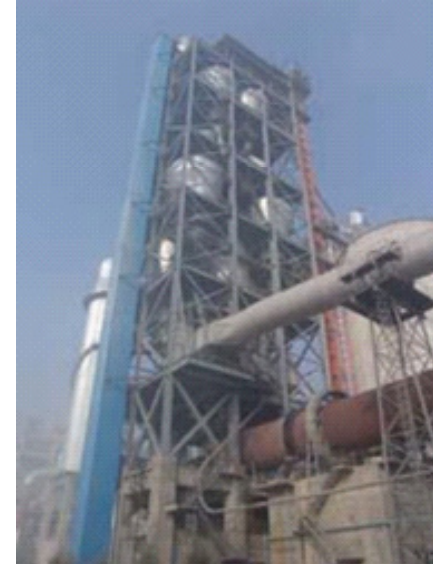

Figure 1. A Rotary Klin in the Cement Company in 2017

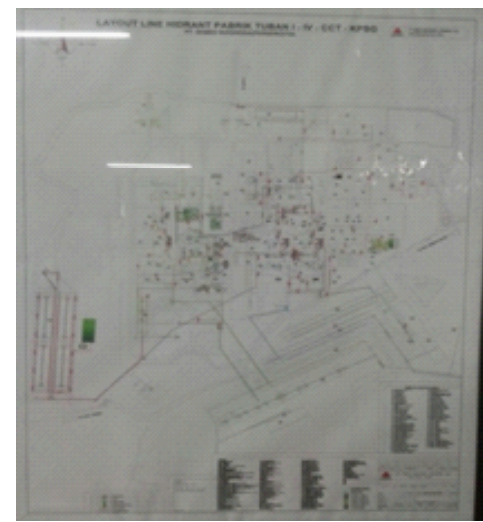

Figure 2. A layout of hydrant in the Cement Company in 2017

and quantity of PPE are sufficient. Moreover, the company has always carried out PPE checks and tests regularly to make sure the PPE are ready to use. The need for personal protective equipment provided has been suitable with workers. The personal protective equipment provides breathing apparatus and oxygen lines, chemical resistant clothing, fire resistant clothing, fire resistant gloves, and boots. Meanwhile, the inspection and maintenance are carried out every day by the Occupational Safety and Health Department.

\section{DISCUSSION}

\section{Causes of Fire at Cement company}

The cement company has the potential to cause a fire with moderate criteria. The potential fire area is located in the cement production area, especially in the coal mill and rotary clin area. A

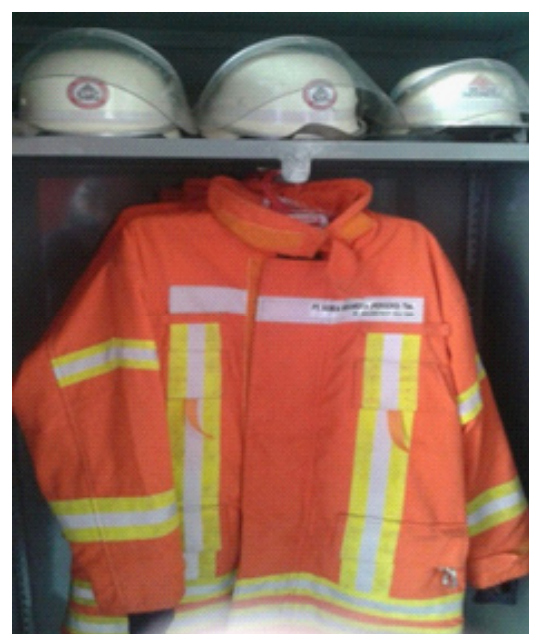

Figure 4. Fire Personal Protective Equipment and Fire-Resistant Clothing

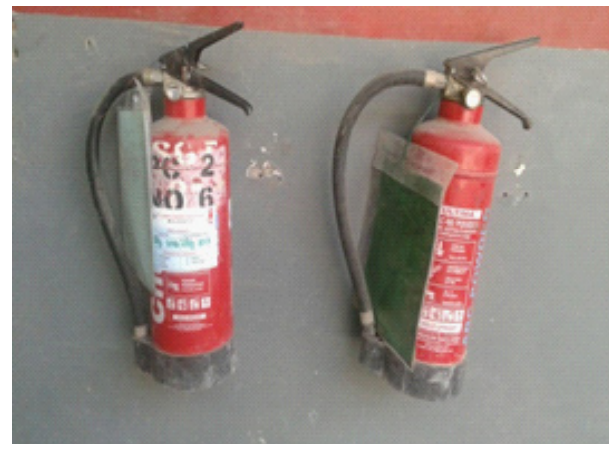

Figure 3. The Condition of Fire Extinguishers in the Cement Company in 2017

fire triangle theory explain that a fire can occur if three elements meet and react with each other. These elements include fuel, oxygen, and heat. In the area of cement production, the cement company has all three elements of the fire triangle, so a fire could occur in the cement production area. This is in line with previous research which states that fires occur because of the 3 elements of fire which include fuel, heat sources and oxygen. These three elements of fire, if they interact with each other, will cause a fire (Umamah, Denny and Kurniawan, 2015).

Based on the Minister of Manpower and Transmigration (1980), fire classification is divided into 4 classes namely class A, class B, class C, and class D. From the results of fire observations in the cement company, the fire is classified as a Class B fire because it ignites flammable liquids, gas, and solid fuels. In the cement company, the use of coal as the main fuel in the process of making cement is a source of fire. 
Furthermore, the firefighting team owned by the company is included in the criteria A because it has included a fire prevention technical course in one of the OSH guidance services. The firefighting team of the cement company is not only responsible for extinguishing the fire in the event of a fire, but also serving as an evacuation team and providing first aids for victims if a fire hazard occurs in the company. Because of a lack of human resources in this fire department, if there is a fire hazard, there are other teams that help, such as from the occupational safety and health section and also the work unit where the fire occurs. The Minister of Manpower (1999) mention the requirements of fire prevention teams that have already received technical courses on fire prevention. The team members at this cement company have also received a certificate from the company's OSH guidance course so that the certified firefighting team members must comply with the regulations (Miranti and Mardiana, 2018)

The production process used in the cement industry involves high energy because it requires a lot of fuel in the production process. Fuel is widely used in preheater and rotary kiln devices as the main burner in the cement production process. Fuel financing spends up to $30 \%-40 \%$ of the production costs (Arifiansyah, 2017).

A rotary kiln is the most important tool needed in the process of making cement. The main use of the rotary kiln is as a place of contact between the hot gas and the material that will later form cementmaking compounds such as $\mathrm{C} 3 \mathrm{~S}, \mathrm{C} 2 \mathrm{~S}, \mathrm{C} 3 \mathrm{~A}$ and $\mathrm{FCaO}$. In order to get good cement yields the $\mathrm{C} 3 \mathrm{~S}$ levels should be $55 \%-62 \%$ and $\mathrm{FCaO}$ levels should be $<2 \%$ (Boateng, 2008).

The location of the cement company which is often at risk of fires is in the rotary kiln. The rotary kiln is the most important equipment in the process of making cement. In the rotary kiln a combustion process occurs to dry the water and heat the dried feed so that it reaches the clinkerization temperature. The combustion process that occurs in the kiln furnace is due to the combination between coal and high pressure oxygen, which can cause bursts of fire to temperatures of $1500^{\circ} \mathrm{C}$ (Putri and Amri, 2011).

The cement company has minimized the potential for fires by various methods. One method that is taken by the cement company in minimizing fires, among others, is facilitating adequate fire protection equipment and the placement of fire protection equipment evenly throughout the factory area. The cement company has also implemented an
ISO 31000 Risk Management System and an ISO 14001 Environment Management System.

The efforts made by the cement company comply with the regulation of the Minister of Manpower (1999) about the Fire Fighting Unit at Work article 2 letter $b$ which reads "The obligation to prevent, reduce and extinguish fires in the workplace includes the provision of detection facilities, alarms, fire extinguishers, and evacuation facilities".

Fire prevention can be done by identifying hazards or assessing the risks of equipment, materials, and production processes, where the results can be disseminated to all employees in the company so that all employees in the company know the potential hazards in their workplace and know how to cope if a danger occurs. In this cement company, risk identification and fire risk assessment are carried out on all equipment, raw materials and production processes because potential fire hazards can occur in every company unit. This is consistent with previous research conducted at PT. Adiluhung Saranasegara Indonesia, Bangkalan where the results of the research state that the company has identified hazard and fire risk assessment because one of the production processes in the company is very risky for a fire (Nugraha, 2019).

\section{Efforts to Prevent Fires in Cement company}

All efforts in preventing fires have been carried out by the cement company, and all efforts are included in the good criteria. This is supported by skilled, professional and qualified human resources personnel who are able to identify the fire factors with applicable technical efforts in the cement company.

The implementation of technical efforts carried out by the cement company is also supported by the existence of sufficient funding budget, so the company is able to procure the materials needed in the fire prevention technical efforts. The implementation of the management system is also a carrying capacity in the implementation of fire prevention technical efforts.

The installation of layouts in the cement company is located in multi-storey buildings such as the main building, dormitory with 2 floors and CCR with 3 floors. Moreover, the evacuation signs have already been installed in each work unit. However, there is a less publicity about the layout in the cement company (Suwedi, 2005). This is not in line with the statement of the Minister of Manpower No. 186 of 1999 article 2 concerning fire management 
units in the workplace because the installation of layouts is less publicized to the employees in the cement company, which is actually the task of the OSH section.

Technical efforts that have been made by the cement company are in accordance with previous research stating that the most efficient achievement of a fire protection system requires the involvement of architects, room experts, building contractors, building safety experts, and fire-fighting experts as a form of fire protection engineering (Rijanto, 2010).

The risk of a fire can be avoided by separating materials that have flammable properties or cause flame from other production materials. This action aims to facilitate prevention in the event of a fire because different types of materials burned will also require different handling. This is in accordance with previous research in one of the fertilizer companies where the company has procedures related to fire prevention efforts such as a chemical handling procedure. The procedure aims to ensure that the work can be carried out properly and does not pose a fire hazard (Dewi, 2012).

The company has also arranged the building by giving distance between one building and another. This is done to anticipate the severity of a fire. Therefore, if there is a fire in one of the buildings, it does not easily spread to the surrounding buildings because there has been a predetermined distance during the planning of company construction.

Giving the distance between buildings in the cement company is in accordance with previous research which states that heat transfer during fire can spread widely by means of convection, conduction and radiation (Tanubrata and Wiryopranoto, 2016). Convection is the transfer of heat by means of air through which heat is transmitted and hot gases are formed in the air. During a fire, hot steam will continue to expand from the source of the fire. Conduction is the transfer of heat by transmitting heat to solid materials during a fire. Heat can move through steel, wires, cables, walls, and other materials that can conduct heat. Radiation is the movement by means of electromagnetic waves. The heat energy generated is emitted into the outside air, and the rest is emitted towards the fuel source so that the intensity of the fires increases.

Preventing spread of fire between buildings or buildings can occur when the walls in the building are destroyed. This prevention has been planned by the company before carrying out the company's development process. This cement company has identified buildings that have a risk of fire, so other buildings should not be close to those buildings as they have the potential to spread the fire. The situation of this company is in accordance with another study which state that brick walls have a fire resistance of around 2 hours. However, there have been a convection and radiation source heat transfer before the fire resistance period has been exceeded. This is what causes the reasoning between the room fires (Tanubrata and Wiryopranoto, 2016).

Efforts to prevent fires can also be done by forming good organizations so thatthere are responsibilities of each division that has been formed. The cement company has made fire prevention efforts by separating raw materials that have the potential for fires in the company, and giving the distance between buildings to minimize the severity of fire hazards. In the implementation, all these fire prevention efforts are carried out by employees not only from the OSH section but also from other sections such as the engineers, architects, etc. This is consistent with previous research conducted at PT. Adiluhung Saranasegara Indonesia, Bangkalan which states that the formation of organizations is very necessary to prevent fires both structurally and non-structurally (Nugraha, 2019).

\section{Occupational Safety and Health Organization of Fire Prevention in the Cement Company}

The cement company has formed an organizational structure in the field of fire management so that the evaluation of the OSH organizational structure in the field of fire prevention is conducted well. The cement company also has facilities and infrastructure to support the fire control, namely the availability of fire extinguishers, hydrants, fire alarms, and fire engines.

The use of an active fire protection system is very much needed in this cement company such as fire extinguishers, hydrants, and detectors. The potential for fires in a cement company is very high so that a good protection system is needed to minimize losses due to fire. The most risky units in the cement company are coal, coalmill and rotary kiln storage areas, so extra fire protection is needed in those areas. This is in accordance Widyastuti (2017) also discuss the use of fire protection and and state that the company under the study has installed alarms in each production area. Maintenance and testing of fire protection equipment must also be carried out (Widyastuti, 2017). 
Moreover, light fire extinguishers must be placed in a position that is visible and easy to reach. Fire extinguishers are installed on a wall that is bolted as a reinforcement or placed in a box that is provided with safety glass. There are some conditions of light fire extinguishers that have not been in accordance with the Minister of Manpower and Transmigration (1980) concerning Requirements for the Installation and Maintenance of Light Fire Extinguishers. It is found that light fire extinguishers are not equipped with proper procedures for their use. The maintenance of light fire extinguishers should carried out routinely every month carried out by the fire department (Kowara and Martiana, 2017).

Another fire protection device is a hydrant. Hydrant installations are spread throughout the company area. A hydrant includes a pump and a hydrant motor, while a hydrant box contains 1 hoze and 1 nozzle. In this cement company, it isfound that some hydrants do not meet the requirements, namely the condition of the damaged nozzle.

Cement companies have also provided fire protection equipment in all locations, so that when a fire occurs all employees can immediately find it out through the sirens of the fire protection equipment. The condition of fire protection equipment in this company is included in good criteria because the OSH organization owned by the company is well structured so that inspections are always carried out regarding fire protection equipment. Based on the Minister of Manpower (1999) regarding the Fire Prevention Unit in the Workplace article 2 letter $b$, the cement company has taken control measures for fire prevention efforts in the company through the establishment of OSH organizations including fire extinguishers, fire protection equipment, workshops, safety officers, and quality control.

An OSH organizational structure in fire control in the cement company has good criteria because it is also supported by companies that have implemented an OSH management system, namely SMK3-OHSAS 18001. Thisis in accordance with Ridley (2006) which states that every leader has a direct link to Occupational Safety and Health (OSH) because they have the control to give instructions or directions. By applying the SMK3-OHSAS 18001 policy, it means that the leaders has taken care of the occupational safety and health, which is the most important factor in the workplace.

An Effort to control fires that have been carried out by the company is the establishment of the company's internal fire department. This is consistent with previous research which states that the most important fire prevention effort is to prevent fires through a planned program for the prevention of fires. Fire Extinguisher Unit has the duty to ensure that conditions are safe and avoid conditions that can cause a fire in the company. Every officer in the fire department has been equipped with trainings related to extinguishing the fire using either a light fire extinguisher or a hydrant. In addition, the cement company has also installed smoking ban signs that are scattered throughout the company's location (Nugraha, 2019).

The establishment of OSH organization which is carried out by the company to support fire control is in accordance with Yusa's opinion (2006) stating that the purpose of the OSH Management System is to create a healthy and safety system at work by involving elements of management, labor conditions, and integrated work environment in order to prevent and reduce work accidents.

This cement company also has a workshop building. This building functions as a storage area for firefighting equipment such as PPE equipment, APAR storage area that has expired to be refilled, and other firefighting support equipment. The person in charge of all of the firefighting equipment is the safety officer. The company also has a good organizational structure, and each employee has carried out their main duties and functions.

The OSH organization of fire prevention in the cement company is also one of the ways to create and achieve company's goals. Together with work safety that is the focus of attention, the company should take precautions that not only apply to its workers, but also to visiting guests, employed contractors, invitees, the environment, or other community members who may be affected by the company's activities (Ridley, 2006).

The OSH organization in this cement company has also conducted a fire management audit. The purpose of this auditis to illustrate the results of the program achievements that have been carried out in the company. Routine audits are carried out by internal company parties, namely the OSH organization. This is in accordance with President of the Republic of Indoensia (2012) which states that fire management audit systems must be carried out routinely and systematically by personnel who are competent and are able to use the established methods. Officers who carry out internal audits in this cement company are OSH employees of the K3 
sectionwho have already had competencies related to fire management. Employees from the management system section also take part in conducting the audit, and they are also included in the fire management system auditor training (Widyastuti, 2017).

When a fire is unavoidable, the company must immediately take prompts and appropriate actions to minimize losses. The establishment of a fire emergency response team incorporated in the fire department is carried out by the cement company to deal with fires at an early stage. In this team, there are procedures and responsibilities of each officer.

\section{Personal Protective Equipment}

In the hazard control hierarchy, the use of personal protective equipment is the ultimate control method. PPE provided by the cement company is well managed, so its use is optimal in reducing hazards. The cement company also records the entry and exit of PPE in a graphical form to determine the availability of PPE.

Personal protective equipment in fire prevention efforts is used during fire trainings in the Cement company. The training materials provided consist of how to use proper personal protective equipment, and how to store it. So, when there is a fire, the fire department can use personal protective equipment well. The provision of good personal protective equipment is supported by a well-implemented management system. This is consistent with the opinion of Putra (2010) stating that personal protective equipment must be placed in a strategic location for the emergency team, depending on the chemicals in the workplace and the nature of the type of accidents (Putra, 2010).

The cement company also carries out a routine OSH inspection, including checking the availability of fire extinguisher PPE. This is in accordance with similar research which states that inspection of equipment including fire extinguishers aims to ensure that fire extinguisher equipment can function properly (Kosha and Paskarini, 2017).

In the work area, the cement company has provided personal protective equipment that has been differentiated depending on the type of work. This self protection equipment is fully provided to comply with the rules on the obligation to use personal protective equipment while working. Personal protective equipment for handling fires is different from personal protective equipment for working in general. The cement company has already had personal protective equipment to deal with fires such as helmets, goggles, and fire-resistant clothing.

This cement company has also held trainings to combat fires. The trainings are conducted by the OSH section so that employees know how to cope with fires and what personal protective equipment should be used. These trainings can influence employees because training can change someone's behavior to understand the importance of personal protective equipment (Noviyanto, 2015).

A PPE procurement conducted by the cement company is a form of protection against danger, and the leader's first priority is to protect all his employees as a whole. The use of PPE is only considered necessary if broader protection methods are impractical and unreachable (Ridley, 2006). The provision of PPE conducted by the cement company is also in accordance with the opinion of Ridley (2006) which states that PPE must be in accordance with the hazards faced, must be suitable for its users, has a strong construction, is provided free of charge, and is maintained in good condition.

\section{CONCLUSION}

The cause of the fire at the cement company is the use of coal as the fuel. The type of fire is included in class B. The cement company has made in-house protective measures such as controlling evacuation signs, setting up a fire-fighting team, and providing personal protective equipment that is sufficient both in quality and in quantity.

\section{ACKNOWLEDMENTS}

I would like to thank my colleagues who have helped me in preparing this research article. I would also like to thank all the lecturers and staff of the Occupational Health and Safety Department of Public Health Faculty at Airlangga University who have provided guidance so that this article could be completed on time.

\section{REFERENCES}

Arifiansyah, D. D. (2017) Optimisasi Pembakaran Di Rotary Klin PT Semen Gresik Pabrik Tuban Dengan Model Jaringan SYaraf Tiruan dan Metode Genetic Algorithm. Undergraduated Thesis.Surabaya: Faculty of Industry Technologi Institut Teknologi Sepuluh Nopember. 
Boateng (2008) Rotary Klins Transport Phenomena and Transport Processes. Oxford: Elsevier Inc.

Dewi, R. P. (2012) 'Analisis Implementasi Teknis Pencegahan Dan Penanggulangan Kebakaran Pada Pabrik 1a Dan 1B Di Industri Pupuk X (Berdasarkan Standar Di Indonesia)', Jurnal Kesehatan Masyarakat Universitas Diponegoro, 1(2), pp. 793-805.

Hastutik, F. Y. (2005) Upaya Pencegahan Dan Penanggulangan Bahaya Kebakaran Di PT. Semen Gresik (Persero) Tbk. Pabrik Tuban Jawa Timur. Undergraduate Thesis.Surakarta: Faculty of Medicine Universitas Sebelas Maret.

Kosha, V. M. and Paskarini, I. (2017) 'Evaluasi Sistem Pencegahan Kebakaran di PT. Chaeron Pokphand Indonesia Plant Krian, Sidoarjo, Jawa Timur', JPH RECODE, 1(1), pp. 48-60.

Kowara, R. A. and Martiana, T. (2017) 'Analisis Sistem Proteksi Kebakaran sebagai Upaya Pencegahan dan Penanggulangan Kebakaran (Studi di PT. PJB UP Brantas Malang)', Jurnal Manajemen Kesehatan Yayasan Dr. Soetomo, 3(1), pp. 70-85.

Minister of Manpower (1998) No.03 Tahun 1998 Tentang Tata Cara Pelaporan dan Pemeriksaan Kecelakaan. Jakarta: Minister of Manpower: Minister of Manpower.

Minister of Manpower (1999) Nomor 186 Tahun 1999 Tentang Unit Penanggulangan Kebakaran. Jakarta: Minister of Manpower: Minister of Manpower.

Minister of Manpower and Transmigration (1980) No. 04/Men/1980 tentang SyaratSyarat Pemasangan dan Pemeliharan Alat Pemadam Api Ringan, Minister of Manpower and Transmigration. Jakarta: Minister of Manpower and Transmigration: Minister of Manpower and Transmigration.

Miranti, R. S. and Mardiana (2018) 'Penerapan Sistem Proteksi Aktif dan Sarana Penyelamatan Jiwa sebagai Upaya Pencegahan Kebakaran', Journal of Public Health, 2(1), pp. 23-32.

Notoadmodjo, S. (2012) Metode Penelitian Kesehatan. Jakarta: Rineka Cipta.

Noviyanto, N. D. (2015) 'Penggunaan Alat Pelindung Diri (APD) Pada Pekerja Pengecoran Logam PT. SInar Semesta (Studi Kasus Tentang Perilaku Penggunaan Alat Pelindung Diri (APD) Ditinjau Dari Pengetahuan Terhadap Potensi Bahaya
Dan Resiko Kecelakaan Kerja Pada Pekerja Pengecoran L', Jurnal Kesehatan Masyarakat (e-Journal), 3(1), pp. 417-428.

Nugraha, R. (2019) 'Penerapan Sistem Manajemen Kebakaran Di PT. Adiluhung Saranasegara Indonesia, Bangkalan', The Indonesian Journal of Occupational Safety and Health, 7(3), pp. 378-386.

Permana, D. (2011) 'Peluang dan Tantangan Peningkatan Nilai Tambah Batubara', Puslitbang Teknologi Mineral dan Batubara, 7(1), pp. $1-13$.

Putra, B. K. (2010) Pencegahan Dan Penanggulangan Kebakaran Di PT.Inka (Persero) Madiun Jawa Timur. Undergraduate Thesis.Surakarta: Faculty of Medicine Universitas Sebelas Maret.

Putri, F. A. and Amri, H. (2011) 'Review Industri Semen', Fakultas Matematika dan Ilmu Pengetahuan Alam, 7(2), pp. 1-25.

President of the Republic of Indoensia. (2012) No. 50 Tahun 2012 Tentang Sistem Manajemen Keselamatan dan Kesehatan Kerja. Jakarta: President of the Republic of Indoensia.

Ridley, John (2006) Kesehatan dan Keselamatan Kerja. Edited by L. Simarmata. Jakarta: ERLANGGA.

Rijanto, B. B. (2010) Kebakaran dan Perencanaan Bangunan. 1st edn. Jakarta: Mitra Wacana Medika.

Tanubrata, M. and Wiryopranoto, H. (2016) 'Penjalaran Kebakaran Pada Suatu Konstruksi Bangunan Gedung Akibat Sumber Panas', Jurnal Teknik Sipil, 12(April 2016), pp. 1-98.

Umamah, A., Denny, H. M. and Kurniawan, B. (2015) 'Analisis Upaya Pencegahan dan Pengendalian Kecelakaan Kerja Pada Sebuah Pabrik Semen di Tuban', Jurnal Kesehatan Masyarakat (e-Journal), 3(3), pp. 285-295.

Widyastuti, D. (2017) Studi Pelaksana Audit Manajemen Kebakaran di PT. Semen Tonasa Tahun 2017. Undergraduate Thesis.Makassar: Faculty of Medicine Universitas Islam Negeri Alauddin Makassar.

Yusa, H. (2006) Kesehatan dan Keselamatan Kerja. Jakarta: Penerbit Universitas Indonesia (UIPress). 